\title{
Analisis kesulitan mahasiswa dalam memahami konsep bilangan real
}

\author{
Lalu Sucipto, Mauliddin ${ }^{1}$
}

\begin{abstract}
Abstrak: Penelitian ini bertujuan untuk mengetahui jenis-jenis kesulitan dan faktor-faktor penyebab kesulitan yang dihadapi oleh mahasiswa dalam mengerjakan soal bilangan real. Penelitian ini merupakan penelitian kualitatif dengan menggunakan analisis deskriptif. Data dikumpulkan melalui observasi, tes dan wawancara. Hasil tes dikelompokkan berdasarkan tujuh kategori kesalahan Watson kemudian dilakukan wawancara untuk mengklarifikasi kesalahan tersebut.Hasil penelitian ini menunjukkan bahwa jenis kesalahan yang dominan terjadi pada jawaban mahasiswa berupa jenis kesalahan data tidak tepat, prosedur yang tidak tepat, konflik level respon, dan masalah hirarkhi keterampilan. Kesalahan mahasiswa dalam mengerjakan soal memberikan gambaran kesulitan yang dialami dalam memahami konsep bilangan real. Faktor yang mempengaruhi kesulitan mahasiswa yaitu: materi yang sulit dipahami dan diaplikasikan dalam pemecahan masalah; dan faktor pribadi yang mencakup pola belajar yang tidak baik, sarana pendukung, dan faktor dosen.
\end{abstract}

Kata kunci: Analisis Kesulitan; Konsep; Bilangan Real

\begin{abstract}
This research aims to identify undergraduate students' difficulties and the factors which caused them in solving real analysis problems. This qualitative research applies descriptive analysis. Data is collected through observation, test, and interview. Students' answers on test are categorized into Watson's seven categories of errors then the students are interviewed to clarify the errors. This research reveals that dominant errors encounterd by the students are inappropriate data, inappropriate procedure, response level conclict, and skill hierarchy problem. The errors portrait the difficulties the students encountered. The factors which cause the difficulties are the material is hard to understand and apply to problem solving; and personal factor such as bad learning habits, supporting tools, and the lecturers.
\end{abstract}

Keywords: Difficulty Analysis; Concept; Real Number

\footnotetext{
${ }^{1}$ IAIN Mataram, Indonesia, ciptobajok@gmail.com
} 


\section{A. Pendahuluan}

Analisis real merupakan mata kuliah wajib yang diberikan di program studi Matematika maupun pendidikan Matematika di sebuah perguruan tinggi. Mata kuliah ini biasanya memiliki bobot 3 sks atau 4 sks bergantung pada profil lulusan yang diharapkan dari sebuah program studi. Mata kuliah analisis real terdiri dari beberapa materi utama antara lain: 1) sistem bilangan real, 2) barisan bilangan real, 3) limit fungsi, dan 4) derivatif (turunan) fungsi (kurikulum prodi tadris matematika IAIN Mataram)

Pada program studi Tadris Matematika Fakultas IImu Tarbiyah dan Keguruan (FITK) Institut Agama Islam Negeri (IAIN) Mataram, mata kuliah analisis real juga dijadikan mata kuliah wajib. Mata kuliah ini diberikan kepada mahasiswa tingkat 3 semester genap dengan harapan dapat membekali mahasiswa dalam hal kemampuan analisis, berpikir logis, dan sistematis. Dengan bekal kemampuan ini, diharapkan mahasiswa dapat menyelesaikan masalah-masalah faktual terutama dalam hal pembuktian suatu dalil atau teorema sehingga akan sangat menunjang kegiatan pembelajaran ketika mahasiswa tersebut menjadi pengajar (guru).

Dalam mengikuti mata kuliah analisis real mahasiswa dituntut untuk selalu memiliki kesiapan belajar yang baik disamping tentunya membutuhkan daya nalar dan logika berpikir yang tinggi. Oleh karena itu, kebanyakan mahasiswa menganggap bahwa analisis real merupakan mata kuliah yang sulit. Hal ini berdampak kepada belum optimalnya capaian belajar mahasiswa.

Anggapan bahwa analisis real adalah mata kuliah yang sulit juga terjadi di kalangan mahasiswa program studi Tadris Matematika. Berdasarkan pengalaman dosen pengampu mata kuliah ini, mahasiswa mengalami kesulitan dalam hal mengkonstruksi ide untuk membuktikan suatu dalil atau teorema tertentu. Padahal, pembuktian adalah hal yang sangat esensial dan tidak dapat dipisahkan dalam analisis real. Menurut Knuth (2002), pembuktian berperan: 1) untuk memverifikasi bahwa suatu pernyataan itu benar, 2) untuk menjelaskan mengapa suatu pernyataan itu benar, 3) untuk mengkomunikasikan pengetahuan matematika, 4) untuk menemukan atau menciptakan matematika baru, atau 5) mensistematiskan pernyataan menjadi sistem aksiomatis.

Kurangnya pemahaman mahasiswa terhadap analisis real juga dapat ditemukan berdasarkan nilai mahasiswa yang begitu rendah. Mereka harus mengulang mata kuliah ini di semester yang lain guna memperbaiki 
nilainya. Tanggapannya hampir sama di setiap selesai ujian dan menerima lembaran hasil ujiannya. Misalnya, peserta merasa kesulitan dalam menuliskan ide yang telah didapat, mata kuliah ini adalah mata kuliah yang cukup berat karena berisi pembuktian-pembuktian, perlu tutorial dan lebih banyak tugas, pembahasan soal dan cara menuliskan bukti dengan baik dan benar lebih banyak dibahas dalam kuliah, dan mahasiswa merasa sudah mengerjakan soal dengan benar namun ternyata masih belum tepat (wawancara dengan perwakilan Mahasiswa yang memprogramkan mata kuliah analisis real). Dari tanggapan mahasiswa ini menunjukkan bahwa mahasiswa masih kesulitan mengikuti mata kuliah analisis real, meskipun mata kuliah pendukungnya seperti kalkulus maupun aljabar linear telah diambil oleh mayoritas mahasiswa semester VI.

Hal ini sejalan dengan penelitian Darmadi, Lukito dan Budayasa (2013) tentang kesulitan berpikir visual mahasiswa dalam memahami definisi formal pada barisan bilangan real. Hasil penelitiannya mengungkapkan bahwa mahasiswa masih memiliki kesulitan dalam memvisualisasi definisi formal pada barisan bilangan real. Misalnya, mahasiswa masih sulit dalam memberikan contoh menggambarkan, menjelaskan suatu elemen sesuai dengan konsep, dan menggeneralisasi maupun menarik suatu kesimpulan. Darmadi, dkk (2013) juga mengungkapkan bahwa meskipun materi barisan bilangan real sudah sistematis, namun kurang memperhatikan tingkat kesulitan belajar. Belajar sebaiknya sesuai dengan tingkat kesulitan belajar sehingga mahasiswa dapat merasakan tantangan yang ada, sehingga penting dalam pembelajaran barisan bilangan real tersusun secara bertahap.

Berdasarkan uraian di atas, peneliti berusaha menganalisis titik persoalan apa saja yang dihadapi oleh mahasiswa dalam memahami analisis real dan selanjutnya bisa diberikan solusi terhadap persoalan itu. Dalam kasus ini, sasaran utama adalah konsep bilangan real sebagai materi pembuka dalam analisis real dengan harapan bahwa jika persoalan pada materi awal bisa diatasi maka materi selanjutnya bisa dipahami dengan baik. Sebab setiap materi dalam analisis real telah disusun dengan sistematis dan runut, dan merupakan satu kesatuan yang terpadu.

Berdasarkan uraian di atas, penelitian ini berusaha menjawab beberapa pertanyaan berikut: 1) jenis-jenis kesulitan apa yang dihadapi mahasiswa program studi Tadris Matematika FITK IAIN Mataram dalam 
mengerjakan soal bilangan real; 2) apa yang menjadi faktor-faktor penyebab kesulitan yang dihadapi mahasiswa program studi Tadris Matematika FITK IAIN Mataram dalam mengerjakan soal bilangan real.

\section{B. Metode Penelitian}

Penelitian ini merupakan penelitian kualitatif dimana data yang diperoleh berupa kata-kata tertulis atau lisan dari orang-orang dan perilaku yang dapat diamati (Margono, 2010). Pendekatan yang digunakan dalam penelitian ini adalah pendekatan deskriptif. Hal ini disebabkan penelitian deskriptif merupakan penelitian yang dimaksudkan untuk mengumpulkan informasi status suatu gejala yang ada (Arikunto, 2010). Pendekatan deskriptif tidak bertujuan untuk menguji hipotesis tertentu, namun hanya menggambarkan apa adanya tentang suatu variabel, gejala, atau keadaan, yakni keadaan menurut apa adanya pada saat peneltian berlangsung.

Penelitian ini bertempat di IAIN Mataram pada Tadris Matematika, kelas C dan D. Waktu penelitian pada semester genap Tahun Akademik 2015/2016. Sumber data penelitian ini adalah subyek dimana data diperoleh (Arikunto, 2010). Data yang digunakan dalam penelitian ini, yaitu:

a) Data primer: Data diperoleh secara langsung di lokasi atau obyek penelitian. Sumber datanya berasal dari mahasiswa tadris matematika semester VI pada kelas $C$ dan $D$, untuk pertama kali mengambil mata kuliah analisis real. Dalam hal ini berupa pemberian tes materi konsep bilangan real dengan bentuk uraian yang diadopsi dari buku Bartle \& Sherbert (2006) untuk menganalisis jenis kesulitan mahasiswa semester VI tadris Tadris Matematika IAIN Mataram.

b) Data sekunder: Data yang diperoleh atau dikumpulkan oleh orang yang melakukan penelitian dari sumber-sumber yang sudah ada. Sumber data diperoleh dari wawancara dengan mahasiswa semester VI program studi tadris Matematika IAIN Mataram.

Pengumpulan data dilakukan dengan teknik obervasi, tes, dan wawancara. Observasi dilakukan untuk mengamati proses perkuliahan dengan merekam segala aktivitas yang terjadi. Hal ini untuk menguatkan data-data yang diambil dari proses tes maupun wawancara.Data yang dikumpulkan melalui tes adalah hasil tes mahasiswa, yang dilakukan oleh dosen mata kuliah analisis real. Data ini akan digunakan untuk 
menganalisis kesulitan mahasiswa terhadap konsep bilangan real. Wawancara akan dilakukan dengan teknik wawancara yang tidak terstruktur dengan tujuan memberikan ruang bagi peneliti untuk leluasa menggali informasi lebih akurat dan mendalam terhadap faktor-faktor penyebab kesulitan mahasiswa.

Penelitian ini dianalisis dengan menggunakan teknik analisis deskriptif naratif yang terdiri atas tiga alur kerja, yakni: reduksi data, penyajian data, dan penarikan kesimpulan/verifikasi. Miles dan Huberman (1992) menyatakan bahwa analisis data kualitatif dilakukan secara interaktif dan berlangsung secara terus-menerus pada setiap tahapan penelitian sehingga sampai tuntas dan datanya sampai jenuh. Aktivitas dalam analisis data yaitu data reduction, data display, dan conclusion drawing/verification.

Pada proses reduksi, peneliti akan merangkum, memilih hal-hal pokok, menfokuskan pada hal penting, mencari tema, dan polanya agar data yang telah direduksi dapat memberikan gambaran yang jelas dan dapat mempermudah peneliti untuk pengumpulan data berikutnya.Selanjutnya, data disajikan dalam bentuk tabel untuk memudahkan data diorganisir dan dikelompokkan sehingga ditemukan pola hubungan tertentu yang mengarah pada kejelasan data untuk dipahami. Selain itu, tabel tersebut dilengkapi dengan uraian singkat untuk mendeskripsikan data lebih jelas.Tahap penarikan kesimpulan dan verifikasi digunakan untuk menjawab rumusan masalah yang telah ditentukan. Penulisan kesimpulan berupa paparan deskriptif tentang hasil penelitian yang ditemukan, baik berupa jenis kesalahan matematis mahasiswa maupun faktor penyebabnya.

Untuk menjamin keabsahan data, dilakukan uji kredibilitas (derajat kepercayaan) dan transferabilitas (keteralihan). Karena pada penelitian kualitatif lebih ditekankan pada aspek validitas data, bukan reliabilitas hal ini senada dengan pendapat Sugiyono (2006), maka uji konsistensi pada penelitian ini tidak dilakukan. Untuk menunjukkan tingkat kepercayaan terhadap hasil penelitian, dilakukan uji kredibilitas. Sedangkan transferabilitas digunakan untuk menunjukkan derajat ketetapan atau apakah hasil penelitian yang diperoleh dapat berlaku pada populasi dimana sampel diambil atau tidak (Moleong, 2006). Akan tetapi Sugiyono 
(2006) mengatakan bahwa pada penelitian kualitatif, transferabilitas tidak dapat dijamin oleh peneliti, hal ini bergantung pada pandangan pemakai.

Oleh karena itu, hanya uji kredibilitas yang dapat dilakukan oleh peneliti dalam penelitian ini. Kekhawatiran pada tingkat kepercayaan terhadap data dan hasil penelitian dapat dihilangkan dengan melakukan beberapa tindakan, yakni: memperpanjang pengamatan dan keikutsertaan, meningkatkan ketekunan, triangulasi, dan pengecekan oleh informan, hal ini sebagaimana yang diungkapkan oleh Fraenkel \& Wallen (2003) dan Moleong (2006).

\section{TEMUAN DAN PEMBAHASAN}

Model jawaban mahasiswa dianalisis jenis kesalahannya berdasarkan 7 (tujuh) kategori yang diadaptasi dari Watson (dalam Sunardi, 1995) yakni: 1) data tidak tepat, 2) prosedur tidak tepat, 3) data hilang, 4) kesimpulan hilang, 5) konflik level respon, 6) manipulasi tidak langsung, 7) masalah hirarkhi keterampilan. Kesalahan jawaban mahasiswa kelas VIC dan VI D pada tes Analisis Real dirangkum pada tabel berikut:

Tabel 1. Jenis Kesalahan Mahasiswa

\begin{tabular}{|c|c|c|c|c|c|c|c|c|}
\hline \multirow{3}{*}{ 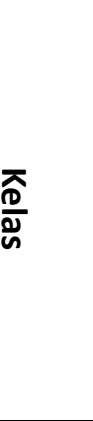 } & \multirow{3}{*}{$\mid \begin{array}{c}\tilde{D} \\
\underline{0}\end{array}$} & \multicolumn{7}{|c|}{ Jenis Kesalahan } \\
\hline & & 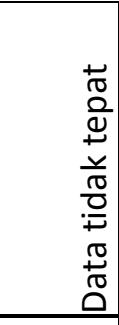 & 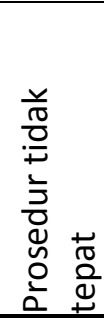 & 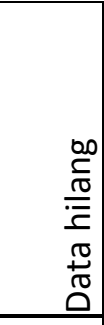 & 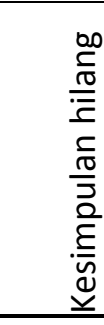 & 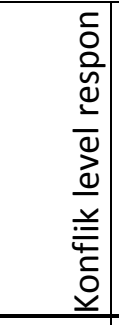 & 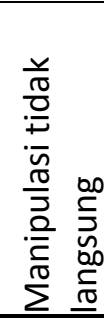 & 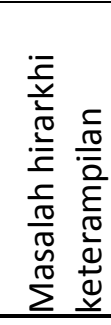 \\
\hline & & 1 & 2 & 3 & 4 & 5 & 6 & 7 \\
\hline \multirow[b]{6}{*}{ VI C } & $1 . \mathrm{i}$ & $100 \%$ & $40 \%$ & $10 \%$ & $10 \%$ & $90 \%$ & $20 \%$ & $100 \%$ \\
\hline & 1.ii & $70 \%$ & $50 \%$ & $30 \%$ & $10 \%$ & $40 \%$ & $0 \%$ & $100 \%$ \\
\hline & 2 & $50 \%$ & $50 \%$ & $0 \%$ & $40 \%$ & $40 \%$ & $40 \%$ & $100 \%$ \\
\hline & 3 & $50 \%$ & $0 \%$ & $10 \%$ & $10 \%$ & $70 \%$ & $0 \%$ & $100 \%$ \\
\hline & 4 & $0 \%$ & $10 \%$ & $0 \%$ & $0 \%$ & $60 \%$ & $0 \%$ & $100 \%$ \\
\hline & 5 & $80 \%$ & $20 \%$ & $50 \%$ & $0 \%$ & $60 \%$ & $0 \%$ & $100 \%$ \\
\hline \multicolumn{2}{|c|}{ Rata-rata } & $58 \%$ & $28 \%$ & $17 \%$ & $12 \%$ & $60 \%$ & $10 \%$ & $100 \%$ \\
\hline \multirow{2}{*}{ VI D } & $1 . \mathrm{i}$ & $50 \%$ & $40 \%$ & $0 \%$ & $10 \%$ & $50 \%$ & $20 \%$ & $90 \%$ \\
\hline & 1.ii & $30 \%$ & $50 \%$ & $0 \%$ & $0 \%$ & $30 \%$ & $20 \%$ & $100 \%$ \\
\hline
\end{tabular}




\begin{tabular}{|c|c|c|c|c|c|c|c|c|}
\hline \multirow{7}{*}{$\frac{\widehat{\widehat{D}}}{\mathrm{~d}}$} & \multirow{3}{*}{$\mid \begin{array}{c}\tilde{0} \\
\underline{0}\end{array}$} & \multicolumn{7}{|c|}{ Jenis Kesalahan } \\
\hline & & 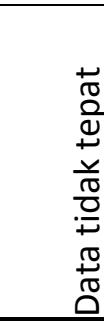 & 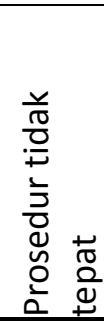 & 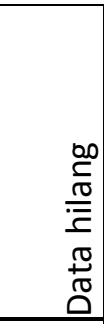 & 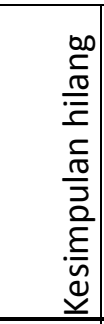 & 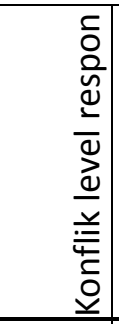 & 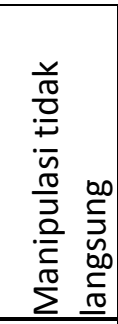 & 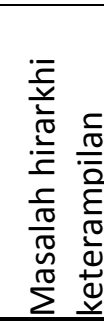 \\
\hline & & 1 & 2 & 3 & 4 & 5 & 6 & 7 \\
\hline & 2 & $10 \%$ & $30 \%$ & $0 \%$ & $0 \%$ & $10 \%$ & $100 \%$ & $100 \%$ \\
\hline & 3 & $50 \%$ & $80 \%$ & $0 \%$ & $0 \%$ & $70 \%$ & $10 \%$ & $100 \%$ \\
\hline & 4 & $70 \%$ & $70 \%$ & $0 \%$ & $0 \%$ & $80 \%$ & $0 \%$ & $100 \%$ \\
\hline & 5 & $20 \%$ & $20 \%$ & $30 \%$ & $10 \%$ & $20 \%$ & $0 \%$ & $70 \%$ \\
\hline \multicolumn{2}{|c|}{ Rata-rata } & $38 \%$ & $48 \%$ & $5 \%$ & $3 \%$ & $43 \%$ & $25 \%$ & $93 \%$ \\
\hline
\end{tabular}

Dari tabel di atas ditunjukkan bentuk kesalahan menjawab mahasiswa mata kuliah analisis real mahasiswa IAIN Mataram kelas VIC terpusat pada masalah hirarkhi keterampilan diamana keseluruh responden melakukan kesalahan ini, kemudian setengah dari responden banyak melakukan kesalahan data tidak tepat dan konflik level. Sedangkan kelas VID sebanyak 93\% pada masalah hirarkhi keterampilan, kemudian rata-rata responden banyak melakukan kesalahan data tidak tepat, prosedur tidak tepat, dan konflik level respon. Peneliti menyadari meskipun kenyataannya responden juga salah dalam memberikan jawaban, yang digolongkan pada tipe kesalahan berupa pengopian data.

\section{Kesalahan pada kelas VIC}

Untuk soal nomor $1 \mathrm{i}$, hampir seluruh model jawaban memperlihatkan tipe kesalahan yang sama yakni jawaban tidak mengikuti prosedur jawaban yang tepat, terjadi konflik level respon, dan masalah hirarkhi keterampilan dalam menuangkan ide dan gagasan. Namun di beberapa model jawaban juga terdapat kesalahan lain, berupa data tidak tepat pada model jawaban 2,3, dan 7; kesalahan manipulasi tidak langsung pada model jawaban 1 dan 4; serta kesalahan kesimpulan hilang pada model jawaban 6

Untuk soal nomor 1ii, jenis kesalahan data tidak tepat, prosedur tidak tepat, konflik level respon, dan masalah hirarkhi keterampilan yang 
mendominasi model jawaban. Hanya pada model jawaban 3 dan 8 terdapat jenis kesalahan data hilang, serta jenis kesalahan data hilang sekaligus kesimpulan hilang pada model jawaban 9.

Untuk soal nomor 2, jenis kesalahan yang ada di setiap model jawaban mahasiswa adalah masalah hirarkhi keterampilan, sedangkan jenis kesalahan kesimpulan hilang, data tidak tepat, prosedur tidak tepat, manipulasi tidak langsung, dan konflik level respon hanya terjadi di empat model jawaban yang berbeda.

Untuk soal nomor 3, jenis kesalahan data tidak tepat,konflik level respon, dan masalah hirarkhi keterampilan mendominasi model jawaban mahasiswa. Sedangkan kesimpulan hilang terjadi pada model jawaban 1, data tidak tepat dan data hilang terjadi pada model jawaban 2, serta prosedur tidak tepat tepat hanya terjadi pada model jawaban 3.

Untuk soal nomor 4, masalah hirarkhi keterampilan dan konflik level respon yang terjadi di hampir seluruh model jawaban mahasiswa. Sementara, data tidak tepat hanya terjadi pada model jawaban 5 .

Untuk soal nomor 5, model jawaban siswa terdapat jenis kesalahan yang mendominasi berupa data tidak tepat, data hilang, konflik level respon, dan masalah hirarkhi keterampilan. Jenis kesalahan prosedur tidak tepat hanya terjadi pada model jawaban 4 dan 6

\section{Kesalahan pada kelas VID}

Pada soal nomor $1 \mathrm{i}$, data tidak tepat, prosedur tidak tepat, konflik level respon, dan masalah hirarkhi keterampilan secara bersamaan terdapat pada model jawaban 4, 7, 8, 9, dan 10. Sedangkan model jawaban 1, 2, dan 6 hanya terdapat kesalahan masalah hirarkhi keterampilan. Untuk prosedur tidak tepat dan kesimpulan hilang, masingmasing terdapat pada model jawaban 3 dan 5.

Pada soal nomor 1ii, jenis kesalahan prosedur tidak tepat dan masalah hirarkhi keterampilan terdapat hampir di setiap model jawaban mahasiswa. Pada soal ini, mahasiswa juga masih melakukan jenis kesalahan data tidak tepat pada model jawaban 1, 6, 10; konflik level respon pada model jawaban $1,6,10$; dan manipulasi tidak langsung pada model jawaban 2,8 .

Pada soal nomor 2, mahasiswa dominan melakukan jenis kesalahan manipulasi tidak langsung dan masalah hirarkhi keterampilan karena 
semua model jawaban yang ada menunjukkan jenis kesalahan tersebut. Jenis kesalahan prosedur tidak tepat ada pada model jawaban 6, 9, 10. Sedangkan data tidak tepat dan konflik level respon hanya ada di model jawaban 5.

Pada soal nomor 3, kasusnya hampir sama dengan soal nomor $1 \mathrm{i}$, yakni kesalahan yang dominan berupa data tidak tepat, prosedur tidak tepat, konflik level respon, dan masalah hirarkhi keterampilan. Hanya saja, pada model jawaban 1 terdapat kesalahan manipulasi tidak langsung.

Pada soal nomor 4, hal yang paling dominan jenis kesalahan mahasiswa dalam menjawab soal Analisis Real adalah data tidak tepat, prosedur tidak tepat, konflik level respon, dan masalah hirarkhi keterampilan. Keempat komponen ini secara bersamaan ada pada model jawaban 2, 3, 4, 5, 8, dan 10. Sedangkan untuk model jawaban 1, 6, 7, dan 9 hanya terdapat satu, dua, atau tiga saja dari keempat komponen tersebut.

Pada soal nomor 5 , jenis kesalahan masalah hirarkhi keterampilan terdapat di semua model jawaban mahasiswa. Untuk model jawaban 3, 7, dan 9, ditambah dengan jenis kesalahan data hilang; model jawaban 4 ditambah dengan jenis kesalahan kesimpulan hilang, sedangkan model jawaban 8 dan 10, ditambah dengan jenis kesalahan data tidak tepat, prosedur tidak tepat, dan konflik level respon.

Berdasarkan hasil yang telah diuraikan, sangat jelas bahwa Analisis Real sebagai mata kuliah wajib bagi Prodi Matematika dianggap dan dirasa sulit oleh mayoritas mahasiswa Matematika IAIN Mataram. Kesulitan ini dapat terlihat pada kesalahan jawaban. Pertama, mahasiswa sulit merespon maksud soal. Jika mahasiswa mengalami hal ini, maka sulit untuk melanjutkan langkah analisis berikutnya. Meskipun kesulitan merespon maksud soal merupakan kesalahan mendasar, namun banyak mahasiswa yang terjebak kasus ini (Gambar 1). Kedua, mahasiswa sudah respon terhadap maksud soal, namun sulit untuk memulai pembuktian. Hal ini terjadi karena mahasiswa tidak terbiasa dengan soal pembuktian, sehingga sulit mengkonstruksi bukti (Gambar 2). Ketiga, mahasiswa sulit menemukan ide atau gagasan guna menguraikan bukti secara urut. Ini bisa terjadi karena kurang adanya latihan dan materi dasar yang sangat lemah (Gambar 3). Keempat, mahasiswa sulit menerapkan teorema dan dalil yang berlaku dalam Analisis Real di dalam mengkonstruksi setiap 
langkah-langkah logis suatu pembuktian untuk mencapai solusi atau kesimpulan. Ini dapat disebabkan oleh lemahnya ilmu pendukung sebagai dasar dan pondasi Analisis Real yang berimbas pada kesulitan memahami teorema dan dalil yang ada, makna dan maksudnya, serta bagaimana penggunaan dan fungsinya (Gambar 4). Kelima, mahasiswa tidak mampu berpikir logis dalam menyusun langkah-langkah bukti yang benar. Bukti tersusun tidak jelas, antara langkah yang satu dengan langkah berikutnya tidak memiliki hubungan, terkesan hadir mengambang tanpa makna, bahkan antara langkah sebelumnya dan setelahnya mengandung nilai yang bertentangan (Gambar 5).

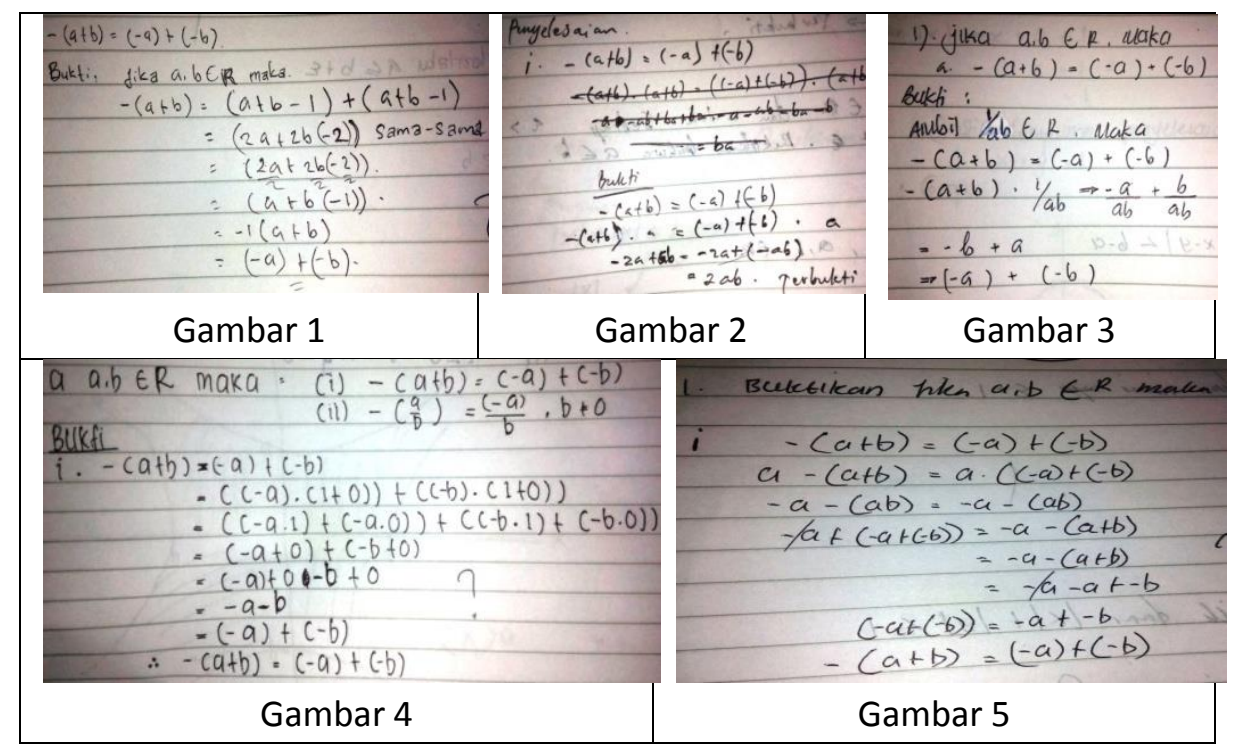

Kesulitan tersebut berlaku hampir di semua mahasiswa Prodi Matematika IAIN Mataram yang mengambil mata kuliah Analisis Real. Khususnya, kelas $C$ dan kelas $D$ pada semester VI yang menjadi subyek penelitian. Umumnya mahasiswa sulit merespon maksud soal dan sulit menemukan ide dan gagasan, sehingga bukti yang dipaparkan tidak memiliki korelasi antara pertanyaan dengan jawaban yang diberikan. Uraian bukti berjalan dengan bebas, di luar kontrol, dan tidak jelas arah dan capaian yang diharapkan.

Kesulitan ini, dapat dilihat pula dari tipe-tipe kesalahan yang dilakukan oleh mahasiswa saat menjawab soal tes. Yang mana, tipe 
kesalahan dianalisis dengan menggunakan 7 jenis kesalahan yakni data tidak tepat, prosedur tidak tepat, data hilang, kesimpulan hilang, konflik level respon, manipulasi tidak langsung, dan masalah hirarkhi keterampilan.

Wawancara sebagai komponen yang tidak dapat dipisahkan dari penelitian ini harus tetap dilaksanakan. Wawancara terhadap mahasiswa kelas VIC dan VID dilakukan pada penelitian ini untuk memperkuat data yang diperoleh. Adapun dari serangkaian jawaban yang telah diberikan oleh mahasiswa sebagaimana uraian hasil wawancara di atas dapat diketahui bahwa mahasiswa masih sulit untuk benar-benar paham terhadap mata kuliah Analisis Real. Hal ini disebabkan oleh berbagai faktor, diantaranya faktor materi kuliah, pribadi mahasiswa, lingkungan, dan dosen.

Dari segi materi, mahasiswa sangat sulit untuk memahami teorema dan dalil yang berlaku dalam Analisis Real, mahasiswa sulit menerapkan teorema dan dalil yang berlaku untuk mengkonstruksi bukti-bukti pada soal pembuktian, mahasiswa belum memiliki bekal atau dasar yang cukup untuk belajar Analisis Real, dan mahasiswa belum memiliki referensi yang cukup untuk memberikan informasi dan wawasan guna memahami materi Analisis Real dengan baik.

Dari sisi pribadi mahasiswa, mahasiswa tidak memiliki pola belajar yang baik dan terstruktur, cenderung malas, dan tidak memiliki daya juang yang tinggi dalam mencapai sesuatu yang diinginkan. Dengan kata lain, mahasiswa cenderung menerima sesuatu dengan apa adanya, tanpa mau berpikir dan berusaha. Mahasiswa belum menampakkan bakatnya di dalam belajar matematika, terlebih pada minat mereka.

Lingkungan juga memberikan peranan yang cukup meyakinkan dalam kesulitan belajar Analisis Real. Hal ini bisa dilihat dari beberapa hal, misalnya ruang belajar yang kurang representatif untuk mendukung proses belajar mengajar di kelas. Mahasiswa merasa tidak nyaman dengan kondisi ruangan yang panas, penat, dan sempit. Di satu sisi mahasiswa harus berebut oksigen di dalam ruang sempit, di sisi lain harus berusaha tetap tenang dan berusaha paham dengan materi yang dibawakan oleh dosen.

Mahasiswa masih mudah terpengaruh oleh kebiasaan belajar teman kebanyakan di lingkungan kampus. Kebiasaan belajar kebanyakan 
mahasiswa adalah belajar karena ujian, bukan karena butuh akan ilmu itu. Hal ini membuat mereka akan sulit memahami materi secara dalam dan mendasar, sehingga ketika dihadapkan oleh berbagai kasus dalam Analisis Real, maka sulit bagi mahasiswa untuk dapat memecahkan kasus tersebut.

Kampus sebagai media untuk menimbah ilmu bagi mahasiswa juga memiliki kontribusi dalam kesulitan mahasiswa dalam belajar Analisis Real. Karena sejak semester 1 hingga semester 6, mahasiswa sangat terbebani oleh mata kuliah-mata kuliah umum dan agama, sehingga mereka tidak memiliki waktu yang banyak untuk memperdalam mata kuliah dasar matematika. Komposisi mata kuliah matematika dan non matematika hampir sama, sehingga keahlian dasar matematika mereka lemah dan rawan, apalagi saat mempelajari mata kuliah Analisis Real yang membutuhkan pemahaman dasar dan konsep yang baik dan mumpuni. Akibat kondisi ini, mahasiswa mengaku bahwa mata kuliah matematika yang dipelajarinya terkadang tidak rampung dan tuntas, terkesan sebatas kulit tanpa isi.

Diakui atau tidak, faktor dosen juga memberikan sumbangan terhadap masalah ini, meskipun tidak dominan. Bisa dikarenakan oleh gaya mengajar dosen, metode pembelajarannya, serta hubungan emosional mahasiswa terhadap dosen. Dalam penelitian ini, terungkap bahwa ada mahasiswa sebagai subjek penelitian memberikan pernyataan bahwa dia tidak suka dengan dosen yang mengajar di kelasnya. Dia bosan, tidak tertarik, bahkan ingin tidur jika dosen mengajar.

\section{Simpulan}

Berdasarkan hasil penelitian dan pembahasan, dapat disimpulkan sebagai berikut:

1. Kesulitan mahasiswa dalam belajar Analisis Real mencakup hal-hal berikut yakni: mahasiswa sulit merespon apa maksud dan tujuan soal, sulit menentukan awal atau permulaan dari suatu pembuktian, sulit menemukan ide dan gagasan, sulit menerapkan definisi, sifat, maupun teorema dalam mengkonstruksi pembuktian, dan mahasiswa masih sulit berpikir logis menentukan langkah-langkah pembuktian yang benar.

2. Jenis kesalahan yang dominan terjadi pada model jawaban mahasiswa, baik pada kelas VIC maupun kelas VID adalah berupa 
jenis kesalahan data tidak tepat, prosedur yang tidak tepat, konflik level respon, dan masalah hirarkhi keterampilan.

3. Faktor yang membuat mahasiswa sulit untuk belajar Analisis Real, yaitu faktor materi yang dirasa sulit dipahami, diterapkan, dan diaplikasikan dalam pemecahan masalah, faktor pribadi yang mencakup pola belajar yang tidak baik, malas, dan tidak memiliki daya juang, serta belum memperlihatkan bakat maupun minat dalam matematika. Faktor lingkungan mencakup ruang kuliah yang belum representative, masih terpengaruh oleh gaya belajar teman yang belajar karena ujian bukan karena kebutuhan, serta kampus yang memberikan beban kuliah yang non matematis yang terlalu banyak, sehingga menyita dan memberikan ruang sempit untuk matematis. Faktor dosen juga berpengaruh, dari gaya mengajar, metode pembelajaran, serta ikatan emosional mahasiswa terhadap dosen yang bersangkutan.

Berdasarkan hasil penelitian ini, saran yang dapat diberikan yaitu:

1. Dosen harus berupaya menciptakan suasana belajar yang menyenangkan dan kondusif yang dapat mendukung proses perkuliahan sesuai target

2. Pihak jurusan harus berupaya untuk melengkapi fasilitas ruang belajar yang dapat mendukung suasana yang baik dan nyaman, agar perkuliahan bisa terlaksana sesuai dengan visi dan misi jurusan

3. Pihak kampus harus mempertimbangakan kembali atas kebijakan konten mata kuliah yang belum pro pada jurusan matematika. Dengan kata lain, harus memperjelas tujuan yang diharapkan dari Prodi Matematika, dengan memperbanyak konten mata kuliah matematika berdasarkan komposisi yang tepat, agar lulusan matematika IAIN Mataram mampu bersaing di bidangnya.

\section{Daftar Pustaka}

Arikunto, S. (2010). Manajemen penelitian. Jakarta: Rineka Cipta

Bartle, R. G \& Sherbert, D. R. (2006). Introduction to real analysis. New York: Wiley.

Darmadi, Lukito, A \& Budayasa, K. (2013). Analisis kesulitan berpikir visual dalam memahami definisi formal pada barisan bilangan real. Yogyakarta. Disampikan di Seminar Matematika dan Pendidikan Matematika di Jurusan Pendidikan Matematika FMIPA UNY.

Fraenkel, J. \& Wallen, N. (2003). How to design and evaluate research in education. New York: McGraw Hill Companies. 
Knuth, E.J. (2002). Secondary School Mathematics Teachers' Conceptions of Proof. Journal for Research in Mathematics Education, 33 (5), 379-405.

Miles \& Huberman. (1992). Analisis Data Kualitatif. Diterjemahkan oleh Tjetjep Rohendi Rohidi. Jakarta: UI Press.

Margono. (2010). Metodologi penelitian pendidakan. Jakarta: Rineka Cipta.

Moleong, L. (2006). Metodologi penelitian kualitatif. Bandung: PT. Remaja Rosdakarya.

Sugiyono. (2006). Metode penelitian kuantitatif, kualitatif, dan $R \& D$. Bandung: Alfabeta.

Sunardi. 1995. Analisis kesalahan mahasiswa dalam menyelesaikan soal geometri analitika ruang berdasarkan taksonomi SOLO. Surabaya: Tesis Pasca Sarjana IKIP Surabaya (Tidak Diterbitkan). 
Lampiran 1

\section{Soal Tes Analisis Real}

1. Bukatikan jika $a, b \in \mathbb{R}$ maka:
(i). $-(a+b)=(-a)+(-b)$
(ii). $-\left(\frac{a}{b}\right)=\frac{(-a)}{b}, \mathrm{~b} \neq 0$

2. Jika a€ $\mathbb{R}$ dan memenuhi a a $=$ a maka buktikan bahwa $a=0$ atau $a=1$

3. Misalkan $a, b \in \mathbb{R}$ dan untuk setiap $\varepsilon>0$ berlaku $a \leq b+\varepsilon$, maka buktikan bahwa $a \leq b$.

4. Buktikan jika $a<x<$ b dan $a<y<b$, maka $|x-y|<b-a$. Berikan interpretasi secara geometris.

5. Tentukan Himpunan Penyelesaian $|x|+|y| \leq 1$ dan sketsa grafiknya. 